\title{
Cranial neuropathies and COVID-19
}

\section{Neurotropism and autoimmunity}

Fiona Costello, MD, FRCPC, and Marinos C. Dalakas, MD, FAAN

Neurology ${ }^{\circledR}$ 2020;95:195-196. doi:10.1212/WNL.0000000000009921

The coronavirus disease 2019 (COVID-19) global pandemic, caused by severe acute respiratory syndrome coronavirus 2 (SARS-CoV-2), began in late 2019. Like its predecessors, severe acute respiratory syndrome coronavirus (SARS-CoV) and Middle East respiratory syndrome coronavirus (MERS-CoV), SARS-CoV-2 binds to angiotensin converting enzyme 2 (ACE2) receptors to facilitate tissue invasion and potentially gain entry into the nervous system. ${ }^{1}$ This single-stranded RNA virus shares $75 \%-80 \%$ identical genome sequence with MERS-CoV and SARS-CoV, but has increased virulence, persistence, and lethality. ${ }^{2}$ Amid catastrophic human suffering, severe neurologic complications of COVID-19 have been identified, yet subtle neurologic manifestations likely have been underreported.

Two recent reports in Neurology ${ }^{\circledR}$ have expanded the neurologic spectrum of COVID-19 disease. Gutiérrez-Ortiz et al. ${ }^{3}$ describe one patient with Miller Fisher syndrome (MFS) and another with cranial neuropathies. Both developed ocular motility deficits after a viral prodrome of fever, anosmia, and ageusia. ${ }^{3}$ The patient with MFS had elevated CSF protein, positive serum anti-GD1b ganglioside antibodies, and a swift therapeutic response to IV immunoglobulin (IVIg). Both patients had lymphopenia, yet their CSF was acellular and aseptic. Dinkin et al. ${ }^{4}$ describe 2 patients with COVID-19 with ocular motor palsies and mild respiratory symptoms. One, with presumed MFS, had MRI features of oculomotor nerve thickening and enhancement. A second, presenting with an isolated sixth nerve palsy, demonstrated MRI enhancement of the optic nerve sheaths and posterior Tenon capsules. These features were interpreted as viral leptomeningeal invasion, despite normal CSF. ${ }^{4}$ Both reports illustrate early occurrence of cranial neuropathies in COVID-19, and highlight the importance of recognizing this clinical association, particularly in patients with hypogeusia, hyposmia, and lymphopenia. ${ }^{3,4}$ The strength of the report by Gutierrez-Ortiz et al. is the demonstration of MFS with GD1b antibodies, whereas Dinkin et al. present novel imaging findings. Together, they inform our growing understanding of COVID-19-associated Guillain-Barré syndromes (GBS), which often affect cranial nerves. ${ }^{2}$

It has hitherto been unclear whether cranial neuropathies as early neurologic manifestations of COVID-19 infection arise from direct viral infiltration of the nervous system or as an autoimmune response. In the only large-scale observational study, of 214 patients with COVID-19, $36.4 \%$ had neurologic findings, including cerebrovascular events, cranial nerve abnormalities (hyposmia, hypoageusia, vision impairment), and muscle injury (myalgia, elevated creatine kinase). ${ }^{5}$ The mechanisms of neurologic injury were unclear, but systemic inflammatory response syndrome, sepsis, multiorgan failure, and possibly viral interaction with ACE2 receptors in nerves, muscle, and brain were tenable considerations. ${ }^{5}$ Accordingly, it remains unclear whether COVID-19 gains access to the nervous system (neuroinvasion), infects neurons and glial cells (neurotropism) inducing neurologic disease (neurovirulence), or triggers autoimmune diseases. ${ }^{6}$

\section{Correspondence}

Dr. Costello

Fiona.Costello@

ahs.ca or Dr. Dalakas

mdalakas@med.uoa.gr

\section{RELATED ARTICLES}

Miller Fisher syndrome and polyneuritis cranialis in COVID-19

Page 211

COVID-19 presenting with ophthalmoparesis from cranial nerve palsy

Page 221

\section{MORE ONLINE}

\section{COVID-19 Resources}

For the latest articles, invited commentaries, and blogs from physicians around the world NPub.org/COVID19 
The association between cranial neuropathies and COVID-19 provides the impetus to explore neuroinvasion and autoimmunity. Evidence of neurologic injury has been described in patients infected with SARS-CoV and MERS-CoV, potentially arising from hematogenous spread or neuronal retrograde dissemination. ${ }^{1,6}$ Specifically, COVID-19 may infect endothelial cells, compromising the integrity of the bloodbrain barrier, or infiltrate leukocytes that become subsequent viral reservoirs for dissemination. ${ }^{1,6}$ Macrophages expressing ACE2 receptors may augment systemic inflammation, perpetuating widespread tissue injury. Coronaviruses may also access the nervous system through neuroepithelium of the olfactory nerve and olfactory bulb or via retrograde axonal transport through other cranial nerves. ${ }^{1,6}$ Indeed, cranial nerve involvement may reflect COVID-19 neurovirulence, because anosmia affects up to $50 \%$ of infected patients. ${ }^{2}$ Interestingly, MRI features depicting cranial nerve, root, and meningeal involvement may represent neuroinvasion, or alternatively edematous neuroinflammation.

There is mounting evidence that cranial nerve involvement in COVID-19 represents autoimmunity, as in GBS cases. ${ }^{2}$ First, GBS is the prototypical postviral induced neuropathy seen in $70 \%$ of cases with known triggers, including influenza, enteroviruses, H1N1, West Nile virus, Zika, MERS-CoV, and SARS-CoV. ${ }^{7}$ Second, in 7 of 11 tested patients with COVID$19 \mathrm{GBS}^{2}$ the virus was absent in acellular CSF, implying no direct root infection or intrathecal viral replication. Third, the noted improvement with $\mathrm{IVIg}^{2-4}$ suggests an ongoing immune response, similar to other autoimmune disorders. Fourth, the anti-GD1b ganglioside antibodies in the patient with MFS, ${ }^{3}$ contrary to typically observed anti-GQ1b, ${ }^{7}$ suggest novel implications. Gangliosides, particularly those containing a disialosyl moiety (GD1b, GQ1b, and GT1b), serve as antigens in patients with neuropathies. ${ }^{8}$ When immunoglobulins recognize epitopes containing disialosyl groups of GD1b on dorsal roots, a sensory ataxic neuropathy can result, including ophthalmoplegia. ${ }^{9}$

The role of gangliosides in driving peripheral nerve autoimmunity is intriguing, because attachment of COVID-19 spike S-proteins to respiratory cells is mediated not only by ACE2 receptors, but also by binding to sialic acid-containing glycoproteins and gangliosides on cell surfaces. ${ }^{10}$ Accordingly, cross-reactivity between epitopes within the COVID-19 spike-bearing gangliosides and signature sugar residues of surface peripheral nerve glycolipids is a possibility. ${ }^{2}$ Such molecular mimicry exists between peripheral nerve glycolipids and Campylobacter jejuni and Zika virus infections, which are known triggers for GBS. ${ }^{7}$ Considering that gangliosides within ocular motor nerves account for antiganglioside antibodies seen in some postinfectious ophthalmoplegias, ${ }^{7}$ such cross-reactivity may explain cranial neuropathies in COVID19. Finally, the binding affinity of chloroquine to sialic acids and gangliosides has notable treatment implications. In the presence of chloroquine, the SARS-CoV viral spike cannot bind gangliosides to infect targeted cells. ${ }^{10}$ Whereas clinical improvement was observed in one treated patient with COVID-19 MFS, ${ }^{4}$ the therapeutic role of chloroquine remains unclear.

The global pandemic has underscored the need to understand the neurotropic potential of COVID-19 and mechanisms by which the virus may trigger autoimmunity. To this end, neurologists have a vital role to play. Vigilance will be needed to detect and treat COVID-19-related immune-mediated disorders. To the extent possible, screening for autoantibodies in cases of neuropathies, myopathies, and encephalitides should be performed. Moreover, early initiation of immunotherapy, specifically IVIg, should be considered, when indicated clinically, to offer protective antibodies, ameliorate cytokine effects, and facilitate hospital discharge. The art of practicing innovative clinical medicine is challenging during this pandemic, but nonetheless imperative. Through skillful evaluation, neurologists can alleviate the burden of complications in their patients, inform scientific understanding of the disease, and contribute to therapeutic advancements for COVID-19.

\section{Study funding}

No targeted funding reported.

\section{Disclosure}

The authors report no disclosures relevant to the manuscript. Go to Neurology.org/N for full disclosures.

\section{References}

1. Baig AM, Khaleeq A, Ali U, Syeda H. Evidence of the COVID-19 virus targeting the CNS: tissue distribution, host-virus interaction, and proposed neurotropic mechanisms. ACS Chem Neurosci 2020;11:995-998.

2. Dalakas MC. Guillain-Barré syndrome: the first documented COVID-19-triggered autoimmune neurological disease. Neurol Neuroimmunol Neuroinflamm 2020;7: e781.

3. Gutiérrez-Ortiz C, Méndez-Guerrero A, Rodrigo-Rey S, et al. Miller Fisher syndrome and polyneuritis cranialis in COVID-19. Neurology 2020;95:e601-e605.

4. Dinkin M, Gao V, Kahan J, et al. COVID-19 presenting with ophthalmoparesis from cranial nerve palsy. Neurology 2020;95:221-223.

5. Mao L, Jin H, Wang M, et al. Neurologic manifestations of hospitalized patients with coronavirus disease 2019 in Wuhan, China. JAMA Neurol Epub 2020 Apr 10.

6. Desforges M, Le Coupanec A, Stodola JK, Meessen-Pinard M, Talbot PJ. Human coronaviruses: viral and cellular factors involved in neuroinvasiveness and neuropathogenesis. Virus Res 2014;194:145-158.

7. Dalakas MC. Pathogenesis of immune-mediated neuropathies. Biochim Biophys Acta 2015;1852:658-666.

8. Dalakas MC, Quarles RH. Autoimmune ataxic neuropathies (sensory ganglionopathies): are glycolipids the responsible autoantigens? Ann Neurol 1996;39:419-422.

9. Daune GC, Farrer RG, Dalakas MC, Quarles RH. Sensory neuropathy associated with monoclonal IgM to GD1 $1_{\mathrm{b}}$ ganglioside. Ann Neurol 1992;31:683-685.

10. Fantini J, Di Scala C, Chahinian H, Yahi N. Structural and molecular modeling studies reveal a new mechanism of action of chloroquine and hydroxychloroquine against SARS-CoV-2 infection. Int J Antimicrob Agents 2020;55:105960. 


\section{Neurology}

\section{Cranial neuropathies and COVID-19: Neurotropism and autoimmunity}

Fiona Costello and Marinos C. Dalakas

Neurology 2020;95;195-196 Published Online before print June 2, 2020

DOI 10.1212/WNL.0000000000009921

This information is current as of June 2, 2020

\section{Updated Information \& Services}

\section{References}

Citations

Subspecialty Collections

Permissions \& Licensing

Reprints including high resolution figures, can be found at: http://n.neurology.org/content/95/5/195.full

This article cites 9 articles, 3 of which you can access for free at: http://n.neurology.org/content/95/5/195.full\#ref-list-1

This article has been cited by 1 HighWire-hosted articles: http://n.neurology.org/content/95/5/195.full\#\#otherarticles

This article, along with others on similar topics, appears in the following collection(s):

\section{All Neuro-ophthalmology}

http://n.neurology.org/cgi/collection/all_neuroophthalmology

Ocular motility

http://n.neurology.org/cgi/collection/ocular_motility

Viral infections

http://n.neurology.org/cgi/collection/viral_infections

Information about reproducing this article in parts (figures,tables) or in its entirety can be found online at:

http://www.neurology.org/about/about_the_journal\#permissions

Information about ordering reprints can be found online:

http://n.neurology.org/subscribers/advertise

Neurology ${ }^{\circledR}$ is the official journal of the American Academy of Neurology. Published continuously since 1951, it is now a weekly with 48 issues per year. Copyright () 2020 American Academy of Neurology. All rights reserved. Print ISSN: 0028-3878. Online ISSN: 1526-632X.

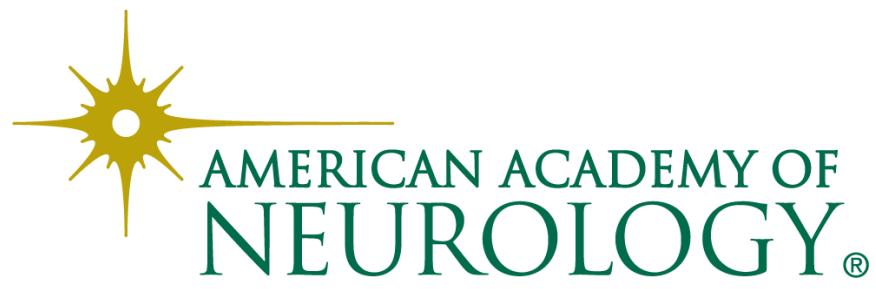

